\title{
Manufacturing and testing of briquettes from inertinite-rich low-grade coal fines using various binders
}

\author{
by N.T. Leokaoke, J.R. Bunt, H.W.J.P. Neomagus, \\ F.B. Waanders, C.A. Strydom, and T.S. Mthombo
}

\begin{abstract}
Synopsis
Inertinite-rich, low-grade coal was used with 12 binders: clays (attapulgite and bentonite), biochar, cow dung, crystallized medium-tar pitch, coal tar sludge, flocculant, fly ash, lignosulphonates, polyester resin, and two South African coal tar pitches in order to produce mechanically strong and water-resistant briquettes. The binders were added in concentrations of $2.5,5,7.5$, and 10 mass $\%$, and the compressive strength, cohesiveness, and water resistance of the resultant briquettes were determined. The briquettes manufactured using lignosulphonate and resin as binders were the strongest, with compressive strengths of 16 and $12 \mathrm{MPa}$ respectively at a 7.5 mass \% binder. Cured and uncured, with and without binder addition, the briquettes all retained their shape and size during drop tests, but none proved to be water-resistant. Paraffin and wax were therefore used as waterproofing agents after pressing and curing. These briquettes showed sufficient strength, cohesiveness, and water resistance to be considered for industrial application.

Keywords agglomeration, binders, coal fines, compressive strength, inertinite, waterproofing.
\end{abstract}

Water resistance is an important factor to be considered during stockpiling and transportation, and a maximum water absorption of 5 mass\% is acceptable for fuel briquettes to be classified as water-resistant (Richards, 1989). Wet briquettes should also be able to withstand a minimum break pressure of $375 \mathrm{kPa}$, as stipulated by Richards (1989).

Binderless agglomeration of vitrinite-rich coal has shown great potential, producing mechanically stronger and more waterproof briquettes compared to inertinite-rich coal (Mangena et al., 2003; Mangena and du Cann, 2006; Motaung, Mangena, and de Korte, 2007). According to Mangena et al. (2003), briquettes produced from vitrinite-rich coal could withstand compression pressures over $1000 \mathrm{kPa}$, while inertinite-rich briquettes produced at the same pressing conditions by Mangena and du Cann (2006) could only tolerate compression pressures up to $720 \mathrm{kPa}$. This was mainly attributed to the distortion and subsequent linking of the reactive macerals into joined masses at the surface of the briquette with pressure, thereby increasing its strength - a phenomenon observed to a lesser extent for inertinite-rich coals (Mangena and du Cann, 2006). Mangena et al. (2003), Mangena and du Cann (2006), and Motaung, Mangena, and de Korte (2007) found that binderless agglomeration of inertinite-rich coal resulted in briquettes with a reduced wet strength, mainly as a result of the kaolinite mineral matter in conjunction with high ash content (> 15 mass\%). Water resistance tests of inertinite-rich, low-grade coals by Mangena et al. (2003) and Mangena and du Cann (2006) resulted either in the disintegration of the briquettes in water or reduced wet strengths compared to their vitrinite counterparts.

* North-West University, Potchefstoom Campus, South Africa.

(c) The Southern African Institute of Mining and Metallurgy, 2018. ISSN 2225-6253. Paper received Feb. 2016; revised paper received Dec. 2016. 


\section{Manufacturing and testing of briquettes from inertinite-rich low-grade coal fines}

Although binderless briquetting is the most economical form of briquetting, use of a binder becomes necessary when briquetting inertinite-rich, low-grade coals (England, 2000; Mangena, 2001; Woods et al., 1963). A binder functions as a coherent or adhesive medium between the fine coal particles, and binding agents are desired for their ability to enhance agglomeration through various mechanisms, depending on their properties.

A suitable binder is required to produce mechanically strong, thermally stable, and water-resistant briquettes in a cost-effective manner (Mills, 1908; Waters, 1969). Coal tar pitch is known to produce mechanically strong and waterproof briquettes (Dehont, 2006; Waters, 1969). The pitch can be added to the coal fines in granular form or in a molten state. Due to the carcinogenic nature of coal tar pitch, it has generally been replaced with bitumen, which possesses similar binding characteristics but produces less harmful fumes (England, 2000). The more environmentally friendly binders, such as starches and molasses, produce goodquality, low-smoke briquettes, but require more intensive thermal post-treatment. The main disadvantage of these binders is the increased processing costs (Dehont, 2006; Waters, 1969). Lignosulphonate and kraft lignin, derived from lignin, which is the strengthening agent in plants and trees, have also been investigated for their binding properties (Boudet, 2000; Ekeberg et al., 2006).

Inorganic compounds such as clays have also been investigated for their suitability as binders. These compounds produce stronger and more water-resistant briquettes at low concentrations and low initial moisture contents of the binder-coal mixture (Gul et al., 2014; Mangena et al., 2003). Materials such as cow manure and municipal solid waste have also been investigated for their binding abilities and were found to increase the reactivity of the resulting briquettes at specific binder concentrations (Massaro, Son, and Groven, 2013; Mishra, Sharma, and Agarwal, 1999). These binders, although affordable, require complex pre- and post-treatment, thereby increasing processing costs.

South African coal resources are mostly comprised of inertinite coal, and this study is therefore aimed at exploring methods of producing mechanically strong and waterproof briquettes from a South African inertinite-rich, low-grade coal. The effect of selected binders and waterproofing agents was determined by means of compressive strength, drop shatter, and water submersion tests.

\section{Materials and methods}

\section{Coal}

A South African, medium-rank C, low-grade, inertinite-rich discard coal (filter cake) from the Highveld area was used. The particle size distribution of the filter cake indicated that $80 \%$ of the sample is below $100 \mu \mathrm{m}$, and it can therefore be classified as ultra-fine. The chemical, mineralogical, and petrographic analyses of the coal fines are given in Table I. The proximate and X-ray diffraction (XRD) analysis indicated an ash content of 23 mass\% with high levels of kaolinite. The inertinite content of the coal is 56 mass $\%$, as seen from the petrographic analysis. Oven drying the sample at $105^{\circ} \mathrm{C}$ indicated a surface moisture of 20 mass $\%$ (as received) for the filter cake. For comparison, the run-of-mine

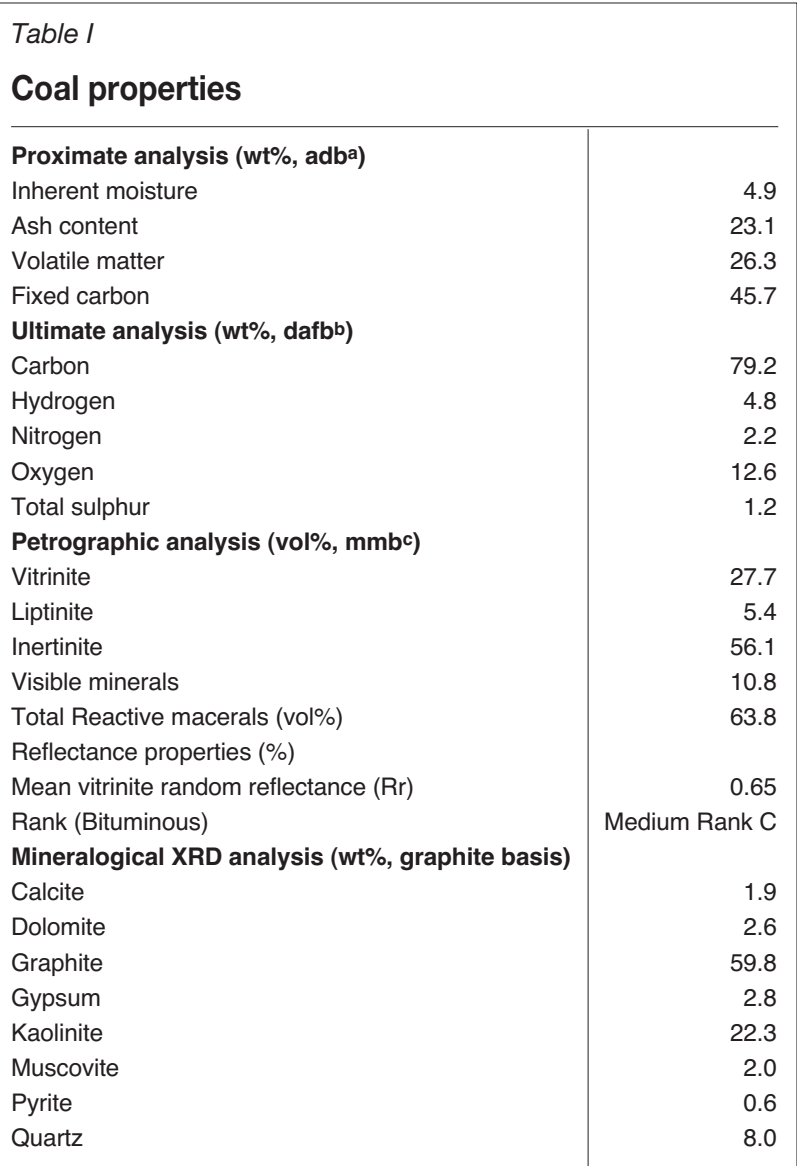

aadb - air-dried basis,

bdafb - dry, ash-free basis

$\mathrm{cmmb}$ - mineral matter basis

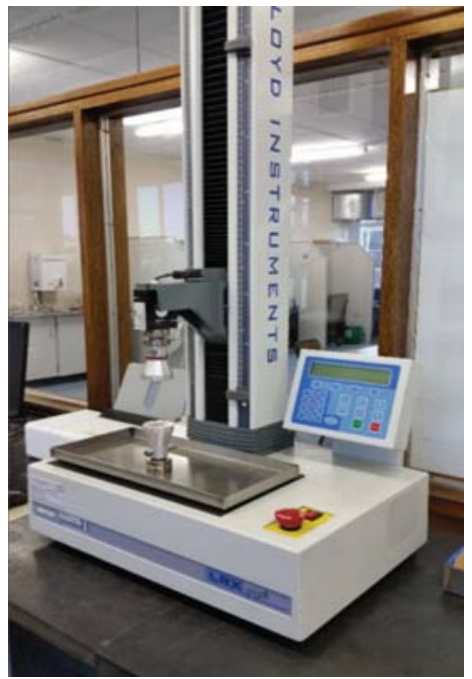

Figure 1-Lloyd LRX press

(ROM) coal from the same colliery was obtained and analysed.

\section{Additives}

The binders used are summarized in Table II. The clays, lignosulphonate, kraft lignosulphonate, pitches, as well as the crystallized medium-tar pitch (MTP) were milled using a 


\section{Manufacturing and testing of briquettes from inertinite-rich low-grade coal fines}

\begin{tabular}{|c|c|c|c|c|}
\hline \multicolumn{5}{|c|}{ Origin, pre-treatment requirements, and costs of the binders and waterproofing agents utilized } \\
\hline Binder & Abbreviation & Origin/supplier & Pretreatment & ${ }^{*}$ Cost (R/ton) \\
\hline $\begin{array}{l}\text { Clays (attapulgite and } \\
\text { bentonite) }\end{array}$ & $\mathrm{A} / \mathrm{B}$ & $\begin{array}{l}\text { Yellowstone bentonite mine near } \\
\text { Koppies, South Africa }\end{array}$ & Milling & 195 \\
\hline Biochar & $\mathrm{BC}$ & $\begin{array}{l}\text { Sunflower husks from a farm in the } \\
\text { North West Province }\end{array}$ & None & - \\
\hline Cow manure & $\mathrm{CM}$ & From a farm in the North West Province & Grating & - \\
\hline $\begin{array}{l}\text { Magnafloc (high molecular } \\
\text { weight flocculant) }\end{array}$ & $\mathrm{F}$ & South African mining chemicals supplier & $\begin{array}{l}\text { Pre-mix } 24 \text { hours } \\
\text { prior to pressing }\end{array}$ & 40000 \\
\hline $\begin{array}{l}\text { Lignosulphonate and } \\
\text { kraft lignosulphonate }\end{array}$ & $\mathrm{LS} / \mathrm{KL}$ & Paper mill byproduct from Mpumalanga & Milling & 4500 \\
\hline NCS polyester resin & R & NCS Resins & None & 39500 \\
\hline Coal tar pitch - (55/59) & CTP1 & o & & \\
\hline Coal tar pitch - (68/73) & CTP2 & South African petrochemical industry & Milling & - \\
\hline Crystallized medium-tar pitch & MTP & South African petrochemical industry & Milling & - \\
\hline Coal tar sludge & Ст & South African petrochemical industry & None & - \\
\hline Fly ash & FA & South African petrochemical industry & None & - \\
\hline Paraffin & $P$ & Hardware store in the North West Province & None & 1040 \\
\hline Wax & w & $\begin{array}{l}\text { Low temperature Fischer-Tropsch process in } \\
\text { South African petrochemical industry }\end{array}$ & None & - \\
\hline
\end{tabular}

*Supplier provided costs. Intellectual property restrictions applied to costs not disclosed.

ball mill to a particle size below $1 \mathrm{~mm}$ prior to blending with the coal sample. The cow manure was shredded prior to being added to the coal fines. The flocculant granules were added directly to the coal fines and left for 24 hours before pressing. Paraffin and wax, also listed in Table II, were used to improve the water resistance of the briquettes.

\section{Briquetting process}

The briquettes were produced by means of a $13 \times 13 \mathrm{~mm}$ cylindrical die using a Lloyd LRX Plus press, which is shown in Figure 1. The binders were each added in mass concentrations of $2.5,5.0,7.5$, and $10 \%$, but due to the sticky nature of the coal-flocculant mixture, the flocculant was added only up to 4 mass $\%$. Samples of $2.5 \mathrm{~g}$ were prepared and pressed with a force of $4.0 \mathrm{kN}$. The mechanical test results for the briquettes produced with the 12 binders were compared to those of the binderless briquettes, as well as to ROM coal ground and smoothed into $13 \times 13 \mathrm{~mm}$ cylinders.

\section{Curing}

Binderless briquettes were cured at $100^{\circ} \mathrm{C}$ for $1,2,3$, and 4 hours. The optimum curing time was determined as 3 hours by means of compressive strength tests. The binderless briquettes were subsequently cured at 100,200,300, and $400^{\circ} \mathrm{C}$ for 3 hours and an optimum curing temperature of $100^{\circ} \mathrm{C}$ was obtained. The binderless briquettes, as well as briquettes containing binder, were cured at these conditions and compared to the uncured briquettes.

\section{Test procedures}

The physical testing methods as detailed by Mangena et al. (2003), Richards (1989), and Kaliyan and Morey (2009) were used to evaluate the mechanical strength of the briquettes.

\section{Compressive strength test}

A briquette was placed between two flat plates, $50 \mathrm{~mm}$ in diameter. An increasing force was applied to the briquette until it cracked or broke, and this force was recorded as the maximum compressive strength of the briquette (Richards, 1989). Each experiment was repeated four times. The Lloyd LRX Plus press was used to compress the briquettes and the breaking force recorded was converted to a pressure by means of Equation [1] (Richards, 1989).

$$
\sigma=\frac{F_{\max }}{A_{b}}
$$

where $F_{\max }$ is the force applied to fracture or break a briquette $(\mathrm{N})$, and $A_{b}$ is the cross-sectional area of the plane of fracture $\left(\mathrm{m}^{2}\right)$.

\section{Drop test}

Each briquette was dropped twice from a height of $1.85 \mathrm{~m}$ onto a concrete floor and the largest remaining piece was weighed (Kaliyan and Morey, 2009). Drop shatter tests were repeated five times. The cohesiveness of the briquettes was then determined by means of Equation [2].

$$
F=\frac{M_{f}(g)}{M_{i}(g)}
$$

where $M_{i}$ is the initial weight of a briquette $(g)$, and $M_{f}$ the weight of the largest piece after dropping $(g)$.

\section{Water resistance}

In order to determine the water resistance, the briquettes were submerged in water for 2 hours, weighed, and then airdried with periodic weighing until no further significant mass loss was observed (Mangena et al., 2003). The wet strength of the briquettes was also determined by conducting compressive strength tests on the immersed briquettes.

\section{Microscopic surface imaging}

High-definition microscopic images of the surface of the briquettes were obtained and investigated using a Nikon SMZ-1 stereo light microscope. 


\section{Manufacturing and testing of briquettes from inertinite-rich low-grade coal fines}

\begin{tabular}{|c|c|c|c|c|c|c|}
\hline \multirow[t]{2}{*}{ Binder } & \multicolumn{2}{|c|}{ CMCS (mass \%) } & \multicolumn{2}{|c|}{ MCS (MPa) } & \multicolumn{2}{|c|}{ OMCS (\%) } \\
\hline & Uncured & Cured & Uncured & Cured & Uncured & Cured \\
\hline Binderless & - & - & 0.9 & 4.9 & 97 & 99 \\
\hline Attapulgite & 10.0 & 2.5 & 1.1 & 3.3 & 97 & 98 \\
\hline Bentonite & 7.5 & 2.5 & 1.0 & 5.5 & 98 & 98 \\
\hline Biochar & 7.5 & 2.5 & 0.9 & 3.5 & 56 & 93 \\
\hline Cow manure & 7.5 & 2.5 & 0.9 & 2.4 & 47 & 90 \\
\hline Flocculant & 1.0 & 1.0 & 4.1 & 1.4 & 50 & 64 \\
\hline Lignosulphonate & 2.5 & 10.0 & 0.6 & 17.0 & 99 & 97 \\
\hline Kraft lignosulphonate & 5.0 & 7.5 & 0.9 & 3.3 & 97 & 97 \\
\hline Polyester resin & 2.5 & 10.0 & 0.9 & 12.3 & 98 & 100 \\
\hline (55/59) Coal tar pitch & 10.0 & 7.5 & 1.1 & 5.6 & 97 & 98 \\
\hline (68/73) Coal tar pitch & 10.0 & 10.0 & 1.1 & 6.4 & 99 & 98 \\
\hline Medium-tar pitch & 10.0 & 7.5 & 1.0 & 7.1 & 100 & 100 \\
\hline CT sludge & 5.0 & 2.5 & 0.9 & 5.8 & 98 & 100 \\
\hline Fly ash & 2.5 & 5.0 & 0.9 & 3.9 & 98 & 97 \\
\hline
\end{tabular}

\section{Results and discussion}

\section{Binderless briquettes}

Table III summarizes the compressive strength and cohesiveness results for the cured and uncured briquettes manufactured with the pre-selected binders. From Table III, the maximum compressive strength (MCS), binder concentration $\left(C_{M C S}\right)$, and cohesiveness $\left(\theta_{M C S}\right)$ at maximum compressive strength can be seen. Uncured, the binderless briquettes met the minimum requirements set out by Richards (1989), reaching compressive strengths up to 0.9 $\mathrm{MPa}$. Curing increased the mechanical strength, with the cured binderless briquettes yielding a maximum compressive strength of 4.9 MPa. This increase in compressive strength can be attributed to the uniformity in morphology as a result of curing, as also reported by Blesa (2002a). The binderless briquettes retained their shape and size, attaining a cohesiveness of $97 \%$ and $99 \%$ for the cured and uncured briquettes, respectively.

\section{Briquettes with binder addition}

Uncured

Table III shows the binder concentrations required to reach maximum compressive strengths. It can be seen that flocculant is the only binder that significantly enhanced the mechanical strength of the uncured binderless briquettes, with 1 mass\% flocculant addition resulting in a compressive strength of 4.1 MPa. Further increases in flocculant weakened the briquettes, refuting the use of flocculant as a binder at high concentrations. The other binders did not increase the mechanical strength of the briquettes to any significant degree, yielding maximum compressive strengths between 0.9 and $1.1 \mathrm{MPa}$. The briquettes produced with biochar, cow manure, and flocculant were the most friable, with cow manure yielding cohesiveness as low as $47 \%$. The low cohesiveness was attributed to internal fractures that occurred as a result of the addition of this binder.

\section{Cured}

Curing of the briquettes resulted in either no change or an increase in cohesiveness. The binderless briquettes showed a compressive strength increase of $4.0 \mathrm{MPa}$ consequent to curing. This may be attributed to the activation of the binders at elevated temperatures, inducing interaction between the coal and the binders (Blesa et al., 2002b).

The kraft lignosulphonate (at maximum concentration) did not increase the mechanical strength of the briquettes above that of the binderless, cured briquette. This binder left the briquettes brittle after curing, causing a reduction in compressive strength. The fly ash, attapulgite, biochar, cow manure, and flocculant all reduced the mechanical strength of the briquettes with increasing binder concentration.

Both coal tar pitches and MTP increased the compressive strength of the cured, binderless briquettes with every increase in binder concentration. These binders were welldispersed within the briquettes at higher concentrations after heat treatment, which was observed upon breaking the briquettes. On the other hand, bentonite and CT sludge both reduced the strength of the briquettes at concentrations above 2.5 mass $\%$. The CT sludge seeped out of the briquettes at concentrations above 2.5 mass $\%$, creating cracks at the surface of the briquettes, thereby reducing their compressive strength.

The most significant increase in mechanical strength was observed for lignosulphonate- and resin-bound briquettes. The compressive strengths are given in Figure 2 as a function of the binder concentration. The compressive strength increased with every increase in binder concentration. Lignosulphonate-produced briquettes met the minimum requirements, even at the lowest concentration of 2.5 mass\%. At concentrations above 5 mass\%, the lignosulphonate briquettes could withstand pressures above $14 \mathrm{MPa}$, which is above the compressive strength of the ROM coal.

Lignin, the main naturally binding component in lignosulphonate, is an amorphous thermoplastic material which undergoes plastic deformation at low compaction pressures and temperatures within its glass transition temperature (Back and Salmen, 1982), which Irvine (1984) found to be in the range of $60-90^{\circ} \mathrm{C}$. Curing the lignosulphonate-bound briquettes at $100^{\circ} \mathrm{C}$ provided the desired glass transition conditions wherein the cell content of the lignin was activated or 'softened'. The glass transition conditions may also have reduced the viscosity and thus increased the mobility of the binding components in the lignosulphonate (Finney, Sharifi, and Swithenbank 2009). This would result in the diffusion of polymer chains and 


\section{Manufacturing and testing of briquettes from inertinite-rich low-grade coal fines}

chain ends from one fibre into the proximity of an adjacent fibre, thereby increasing the bonding area. Upon cooling, these bonds are consolidated, resulting in the formation of hardened solid bridges (Kaliyan and Morey, 2010).

Another binder producing strong briquettes was the polyester resin, with briquette break strengths above the minimum requirement observed from 2.5 mass\% binder addition. With every increase in resin concentration, an increase in compressive strength was observed, as illustrated in Figure 2. Although the resin is highly viscous at ambient temperature, its mobility was enhanced upon curing, as a result of the decrease in viscosity. This may have resulted in the formation of solid bridges upon cooling, thereby increasing the mechanical strength of the resulting briquettes (Kaliyan and Morey, 2010).

The lignosulphonate- and resin-bound briquettes were further investigated by light microscope imaging, which provided a better visualization of the surface morphology. The light microscopic images (Figure 3) show a significant difference between the binderless briquettes and the briquettes manufactured with the use of lignosulphonate and resin binders. The cracks visible in the binderless briquettes contribute largely to the low mechanical strength compared to the lignosulphonate and resin briquettes. The resin briquette exhibits less voids than the binderless briquette, which also becomes apparent in the mechanical strength differences between the two briquettes. The lignosulphonate briquette has a more uniform surface, exhibiting the least amount of voids; which explains the high compressive strengths attained by the lignosulphonate briquettes.

The costs of each binder as provided by the suppliers are specified in Table II. Zero costs were assumed for the fine discard coal. Addition of 5 mass\% lignosulphonate results in binding costs of R225 per ton of coal. Binding agent costs associated with utilizing resin were determined as R2 963 per ton of coal. Sasol coal mining costs were estimated at R227 per ton for 2016, well comparable to the lignosulphonate binding costs (Sasol, 2016).

\section{Water resistance tests}

The binderless briquettes and briquettes manufactured with

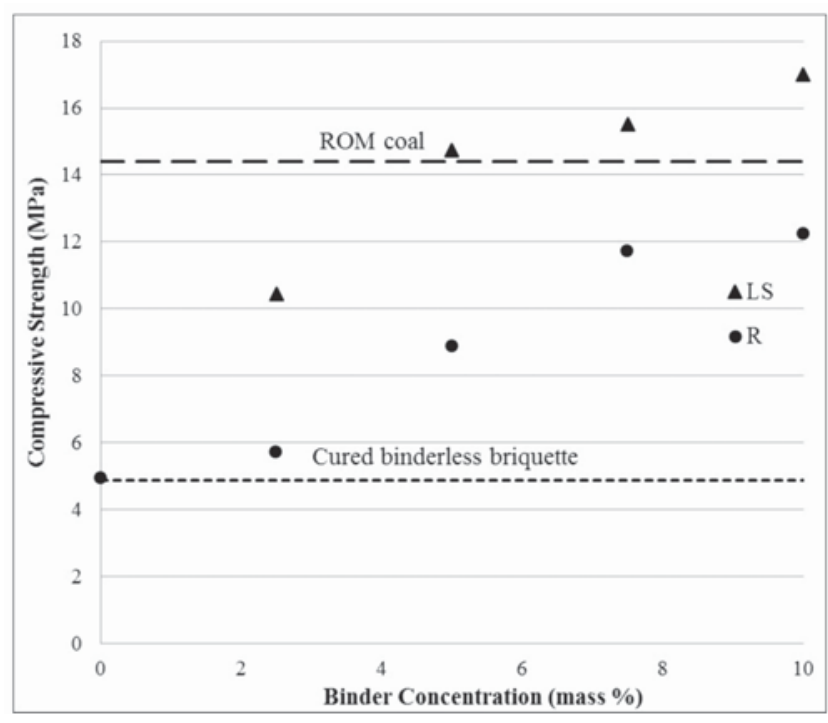

Figure 2-Compressive strengths of cured lignosulphonate- (LS) and resin- $(R)$ bound briquettes as a function of binder concentration
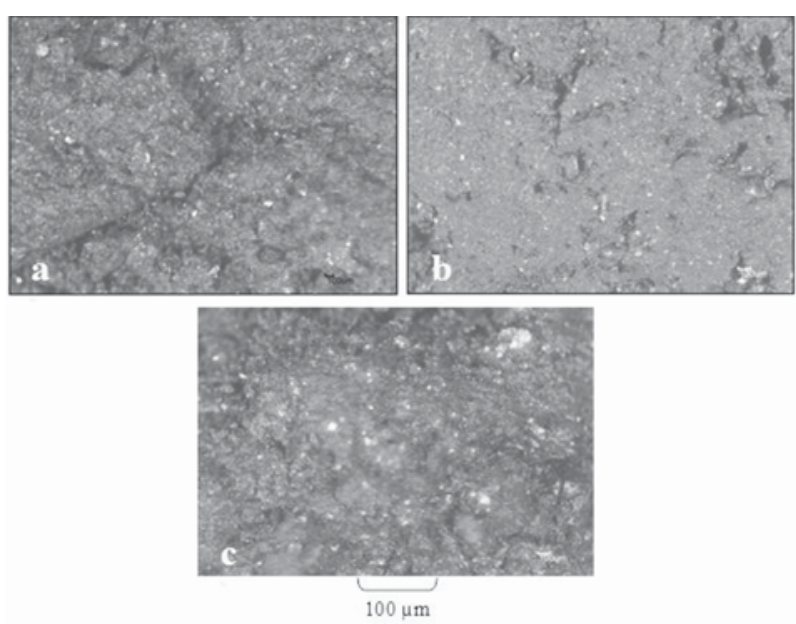

Figure 3-Light micrographs of the surfaces of briquettes containing (a) no binder, (b) lignosulphonate binder, and (c) resin binder

the selected binders all disintegrated within seconds in the presence of water, which was attributed to the high ash and kaolinite clay content (Table I). Mangena et al., (2003) found that kaolinite significantly reduces the water resistance of binderless briquettes when the ash content of the parent coal is above 15 mass\%. This is due to the softening and swelling of kaolinite in the presence of water.

To ensure that manufactured briquettes are comparable to their ROM coal counterparts during storage and utilization, the strongest two briquettes were selected for waterproofing. The only additives considered to improve the water resistance of the briquettes were paraffin and wax, due to their hydrophobic nature. Consequently, these additives were investigated for their use as waterproofing agents for the lignosulphonate and resin-bound briquettes, which yielded the highest compressive strength results.

The wet strength and moisture content of the lignosulphonate- and resin-bound briquettes after waterproofing, water submersion, and air-drying can be seen in Figure 4. Lignosulphonate briquettes yielded better resistance when submerged in molten wax, while the resin briquettes were more water resistant when submerged in paraffin immediately after curing. The lignosulphonate briquettes had an initial moisture intake of 2 mass\%, which decreased with increasing air-drying time. Moisture absorption of 5 mass\% and less was deemed acceptable by Richards (1989). Although the resin briquettes initially absorbed high amounts of moisture (9.3 mass\%), both binders produced briquettes that displayed the minimum compressive strength of $375 \mathrm{kPa}$ as suggested by Richards (1989) for industrial fuel briquettes. The lowest wet strengths attained by the lignosulphonate and resin briquettes were 1.6 and $2.2 \mathrm{MPa}$ respectively, and these briquettes would therefore endure weathering during stockpiling and transportation.

\section{Conclusion}

Briquettes manufactured from inertinite-rich, ultrafine coal ( $23 \%$ ash content) and using suitable binding and waterproofing agents have suitable mechanical properties for industrial application. Lignosulphonate and resin proved to increase the dry strength of the briquettes to a larger extent, producing briquettes that meet the minimum dry strength requirements even at the lowest binder concentration of 2.5 


\section{Manufacturing and testing of briquettes from inertinite-rich low-grade coal fines}

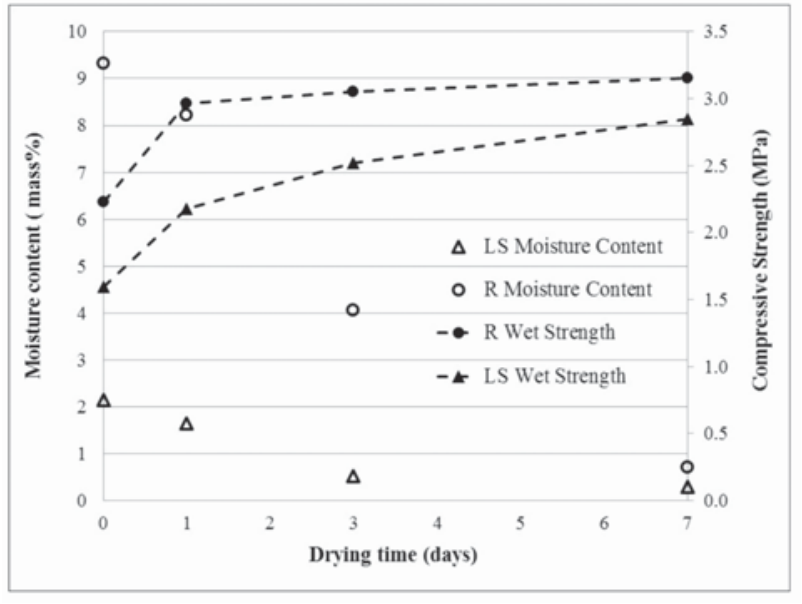

Figure 4-Moisture contents and wet compressive strengths of lignosulphonate (LS) and resin (R) briquettes as a function of air-drying time

mass\%. Due to the high ash and kaolinite contents of the coal, waterproofing was essential. Coating the lignosulphonate briquettes with molten wax and the resin briquettes with paraffin immediately after curing resulted in water-resistant briquettes that met the minimum mechanical strength requirements. The binder costs for lignosulphonate, estimated at R225 per ton coal, were more acceptable compared to the resin (R2 963 per ton coal). An in-depth reactivity analysis of both lignosulphonate- and resin-bound briquettes will be carried out. Considering the mechanical, reactivity and economic results, a final briquette formulation will be selected for pilot-scale testing in a chain grate stoker.

\section{Acknowledgements}

The information presented in this paper is based on research financially supported by the South African Research Chairs Initiative (SARChI) of the Department of Science and Technology and National Research Foundation of South Africa (Coal Research Chair Grant No. 86880).

Any opinion, finding, or conclusion or recommendation expressed in this material is that of the author(s) and the NRF does not accept any liability in this regard.

Facets of the study have been presented at three conferences. A poster presentation was given at the 7 th Annual Granulation Workshop Conference that took place on 2 July 2015 in Sheffield, UK. A paper was presented at the Southern African Coal Processing Society 2015 conference, Coal Processing: Unlocking Southern Africa's Coal Potential, which took place on 27 August 2015 at Secunda in South Africa. The study was also presented at the Fossil Fuel Foundation 2015 conference, Sustainable Energy Research, in Potchefstroom, South Africa on 25 November 2015.

\section{Nomenclature}

$A_{b} \quad$ Cross-sectional area of plane of fracture of the briquette $\left(\mathrm{m}^{2}\right)$

$C_{M C S}$ Binder concentration at maximum compressive strength (mass\%)

$F_{\max }$ Force applied to fracture or break a briquette (N)

MCS Maximum compressive strength ( $\mathrm{MPa})$

$M_{f} \quad$ Weight of the largest piece after drop shatter test ( $g$ )

$M_{i} \quad$ Initial weight of a briquette $(\mathrm{g})$

$\sigma \quad$ Compressive strength $(\mathrm{MPa})$

$\theta$ Cohesiveness (\%)

$\theta_{\text {MCS }}$ Cohesiveness at maximum compressive strength (\%)

\section{References}

BAcK, E.L. 1987. The bonding mechanism in hardboard manufacture. Holzforschung-International Journal of the Biology, Chemistry, Physics and Technology of Wood, vol. 41, no. 4. pp. 247-258.

BACK, E.L. and SALMEN, N.L. 1982. Glass transitions of wood components hold implications for molding and pulping processes. Tappi Journal, vol. 65, no. 7. pp. 107-110.

Blesa, M.J., MiRAnda, J.L., IzQuierdo, M.T., and Moliner, R. 2002a. Curing temperature effect on mechanical strength of smokeless fuel briquettes prepared with molasses. Fuel, vol. 82, no. 8. pp. 943-947.

Blesa, M.J., Miranda, J.L., Izquierdo, M.T., and Moliner, R. 2002b. Curing time effect on mechanical strength of smokeless fuel briquettes. Fuel Processing Technology, vol. 80, no. 2. pp. 155-167.

Boudet, A.M. 2000. Lignins and lignification: selected issues. Plant Physiology and Biochemistry, vol. 38, no. 1-2. pp. 81-96.

DenonT, F. 2006. Coal briquetting technology. http://www.sahutconreur.com [accessed 1 August 2013].

Ekeberg, D., Gretland, K.S., Gustafsson, J., Braton, S.M., and Fredheim, G.E. 2006. Characterisation of lignosulphonates and kraft lignin by hydrophobic interaction chromatography. Analytica Chimica Acta, vol. 565 , no. 1. pp. 121-128.

England, T. 2000. The economic agglomeration of fine coal for industrial and commercial use. CoalTech 2020. Coaltech Research Association, South Africa.

FinneY, K.N., SHARIFI, V.N., and SwithenBank, J. 2009. Fuel pelletization with a binder: Part I - Identification of a suitable binder for spent mushroom compost - coal tailing pellets. Energy and Fuels, vol. 23, no. 6 . pp. 3195-3202.

Gul, A.G., Sirkeci, A.A., Boylu, F., Guldan, G., and Burat, F. 2014. Improvement of mechanical strength of iron ore pellets using raw and activated bentonites as binders. Physicochemical Problems of Mineral Processing, vol. 51, no. 1. pp. 23-36.

IRvine, G.M. 1984. The glass transitions of lignin and hemicellulose and their measurement by differential thermal analysis. Tappi Journal, vol. 67, no. 5. pp. 118-121.

Kaliyan, N. and MoRey, R.V. 2009. Factors affecting strength and durability of densified biomass products. Biomass and Bio-energy, vol. 33, no. 3 . pp. 337-359.

KaLIYAN, N. and MoReY, R.V. 2010. Natural binders and solid bridge type binding mechanisms in briquettes and pellets made from corn stover and switch grass. Bioresource Technology, vol. 101, no. 3. pp. 1082-1090.

MangenA, S.J. 2001. The amenability of some South African bituminous coals to binderless briquetting. MTech dissertation, Technikon Pretoria, Pretoria.

Mangena, S.J., de KoRte, G.J., McCrindle, R.I., and Morgan, D.L. 2003. The amenability of some Witbank bituminous ultra fine coals to binderless briquetting. Fuel Processing Technology, vol. 85, no. 15. pp. 1647-1662.

MANGENA, S.J. and Du CANN, V.M. 2006. Binderless briquetting of some selected South African prime coking, blend coking and weathered bituminous coals and the effect of coal properties on binderless briquetting. International Journal of Coal Geology, vol. 71, no. 2-3. pp. 303-312.

Massaro, M.M., Son, S.F., and Groven, L.J. 2013. Mechanical, pyrolysis and combustion characterization of briquetted coal fines with municipal solid waste plastic (MSW) binders. Fuel, vol. 115, no. 1. pp. 62-69.

MiLls, J.E. 1908. Binders for coal briquettes. US Geological Survey, Washington.

Mishra, S.L., Sharma, S.K., and Agarwal, R. 1999. Briquetting of lignite for domestic fuel. Science and Industrial Research, vol. 59, no. 5. pp. 413-416.

Motaung, J.R., Mangena, S.J., and DE KoRTE, G.J. 2007. Effect of coal composition and flotation reagents on the water resistance of binderless briquettes. Coal Preparation, vol. 27, no. 4. pp. 230-248.

Richards, S.R. 1989. Physical testing of fuel briquettes. Fuel Processing Technology, vol. 25, no. 2. pp. 89-100.

SACRM. 2011. South African coal roadmap. http://www.sanedi.org.za [accessed 31 August 2015].

SAsol. 2016. Additional Analyst Information for the year ended 30 June 2016. Sasol Limited, Johannesburg.

SASTRY, V.S. 1991. Pelletization of fine coals. Department of Energy Report no. DE-FG-22-89PC89766. University of California, Berkeley, California.

WATERS, P.L. 1969. Binders for fuel briquettes. Technical Communication no. 51. CSIRO, New South Wales, Australia.

Woods, M.F., Habberjam, G.M., Elsworth, K., and BennetT, S. 1963. The effect of maceral compostion on the binderless briquetting of hot char. National Coal Board, Cheltenham, England. 